Chronic Obstructive Pulmonary Diseases: Journal of the COPD Foundation

Original Research

\title{
Development of the Advancing the Patient Experience in COPD Registry: A Modified Delphi Study
}

Chelsea L. Edwards, $\mathrm{PhD}^{1}$ Alan G. Kaplan, MD, CCFP(EM) ${ }^{2,3,4}$ Barbara P. Yawn, MD, MSc ${ }^{5,6}$ Janwillem W. H. Kocks, MD, $\mathrm{PhD}^{1,7,8}$ Lakmini Bulathsinhala, $\mathrm{MPH}^{1}$ Victoria A. Carter, BSc ${ }^{1}$ Ku-Lang Chang, MD ${ }^{9}$ Chester Fox, MD ${ }^{10,11}$ Gokul Gopalan, MD ${ }^{12}$ MeiLan K. Han, MD ${ }^{13}$ Maja Kruszyk, BEng ${ }^{1}$ Chantal E. Le Lievre, BPH ${ }^{1}$ Cathy Mahle, PhD, MBA ${ }^{12}$ Barry Make, MD ${ }^{14}$ Wilson D. Pace, MD ${ }^{10,15}$ Chris Price, LLB ${ }^{1}$ Asif Shaikh, MD, MPH ${ }^{12}$ Neil Skolnik, MD ${ }^{16,17}$ David B. Price, FRCGP ${ }^{1,7,18}$

\section{Abstract}

Background: Chronic obstructive pulmonary disease (COPD) is commonly managed by family physicians, but little is known about specifics of management and how this may be improved. The Advancing the Patient Experience in COPD (APEX COPD) registry will be the first U.S. primary care, health system-based registry following patients diagnosed with COPD longitudinally, using a standardized set of variables to investigate how patients are managed in real life and assess outcomes of various management strategies.

Objective: Gaining expert consensus on a standardized list of variables to capture in the APEX COPD registry. Methods: A modified, Delphi process was used to reach consensus on which data to collect in the registry from electronic health records (EHRs), patient-reported information (PRI) and patient-reported outcomes (PRO), and by physicians during subsequent office visits. The Delphi panel comprised 14 primary care and specialty COPD experts from the United States and internationally. The process consisted of 3 iterative rounds. Responses were collected electronically.

Results: Of the initial 195 variables considered, consensus was reached to include up to 115 EHR variables, 34 PRI/PRO variables and 5 office-visit variables in the APEX COPD registry. These should include information on symptom burden, diagnosis, COPD exacerbations, lung function, quality of life, comorbidities, smoking status/history, treatment specifics (including side effects), inhaler management, and patient education/selfmanagement.

Conclusions: COPD experts agreed upon the core variables to collect from EHR data and from patients to populate the APEX COPD registry. Data will eventually be integrated, standardized and stored in the APEX COPD database and used for approved COPD-related research.

\footnotetext{
Abbreviations: chronic obstructive pulmonary disease, COPD; Advancing the Patient Experience in COPD, APEX COPD; electronic health records, EHRs; patient-reported information, PRI; patient-reported health outcomes, PROs; Global initiative for chronic Obstructive Lung Disease, GOLD; Round 1, R1; Round 2, R2; Round 3, R3; American Thoracic Society, ATS; European Respiratory Society, ERS; modified Medical Research Council, mMRC; Optimum Patient Care, OPC; COPD-X Australian and New Zealand Guidelines, COPDX; point of care, POC; APEX COPD Operational Management Group, AOMG; inhaled corticosteroid, ICS; peak inspiratory flow rate, PIFR; forced expiratory volume in 1 second, FEV $\mathbf{1}$; forced vital capacity, FVC; body mass index, BMI; alpha-1 antitrypsin deficiency, AATD; asthma/COPD overlap syndrome, ACOS; respiratory tract infection, RTI; antibiotic, Atb; oral corticosteroid, OCS; chest X-ray, CXR; computed tomography, CT; blood pressure, BP; coronary heart disease, CHD; congestive heart failure, CHF; gastroesophageal reflux disease, GERD; short-acting beta2-agonist, SABA; long-acting beta2-agoinist, LABA; short-acting muscarinic antagonist, SAMA; long-acting muscarinic antagonist, LAMA; phosphodiesterase, PDE; leukotriene receptor antagonist, LTRA; metered-dose inhaler, MDI; electronic cigarette, E-cigarette

Funding Support: APEX COPD is conducted by Optimum Patient Care Global Limited, and co-funded by Optimum Patient Care Global and Boehringer Ingelheim Pharmaceuticals, Inc.
} 
Date of Acceptance: July 13, 2020

Citation: Edwards CL, Kaplan AG, Yawn BP, et al. Development of the Advancing the Patient Experience in COPD registry: a modified Delphi study. Chronic Obstr Pulm Dis. 2021;8(1):135-151. doi: https://doi.org/10.15326/jcopdf.2020.0154

1 Optimum Patient Care, Cambridge, United Kingdom

2 Observational and Pragmatic Research Institute, Singapore

3 Family Physician Airways Group of Canada, Stouffville,

Ontario, Canada

4 University of Toronto, Toronto, Canada

5 University of Minnesota, Minneapolis, Minnesota, United States

6 COPD Foundation, Washington, DC, United States

7 Observational Pragmatic Research Institute, Singapore

8 General Practitioners Research Institute, Groningen,

Netherlands

9 College of Medicine, University of Florida, Gainesville, Florida, United States

10 DARTNet Institute, Aurora, Colorado, United States

11 University at Buffalo, Buffalo, New York, United States

12 Boehringer Ingelheim, Ridgefield, Connecticut, United States

13 University of Michigan, Ann Arbor, Michigan, United States

14 Department of Medicine, National Jewish Health, Denver, Colorado, United States

15 University of Colorado, Denver, Colorado, United States

16 Thomas Jefferson University, Jenkintown, Pennsylvania, United States

17 Abington Jefferson Health, Jenkintown, Pennsylvania, United States

18 Centre of Academic Primary Care, Division of Applied Health Sciences, University of Aberdeen, Aberdeen, United Kingdom

\section{This article contains an online supplement.}

\section{Address correspondence to:}

Professor David B. Price

Academic Primary Care

Division of Applied Health Sciences

University of Aberdeen, Polwarth Building

Foresterhill, Aberdeen

AB25 2ZD, UK

Phone: +65 69623627

E-mail: dprice@opri.sg

\section{Keywords:}

primary care; patient-reported outcomes; research; clinically relevant data collection; registry

\section{Introduction}

Chronic obstructive pulmonary disease (COPD) is managed predominantly by family physicians, but little is known about how this prevalent disease is managed in primary care, or how primary care management in the United States may be improved. Management of this disease is daunting when one considers the sheer size of the population (16 million U.S. adults and rising), ${ }^{1,2}$ the continuing rise in
COPD-related mortality, ${ }^{3,4}$ the high symptom burden experienced by patients, ${ }^{5}$ and the cost to the U.S. economy (predicted $\$ 50$ billion by the end of 2020). ${ }^{6}$ The prevalence and burden of COPD are predicted to increase over the coming decades due to continued exposure to COPD risk factors (tobacco smoking, air pollution) and aging of the population. ${ }^{7}$ Although the Global initiative for chronic Obstructive Lung Disease (GOLD) strategy provides clear strategies for COPD diagnosis and management, ${ }^{8}$ they are often not fully understood nor implemented in primary care practice. ${ }^{9}$ COPD remains a disease which is underand mis-diagnosed, resulting in delayed and/or suboptimal disease management. ${ }^{10-12}$ The question remains, how do we ensure optimum management of COPD patients in primary care?

Both primary care- and patient-related factors make this a difficult question to answer. The issues in primary care include a reticence to diagnose COPD in already multimorbid patients, the temptation to prescribe antibiotics for patients who present with chest infections/bronchitis rather than delving into a COPD diagnosis protocol, and a lack of understanding (or indeed, availability) of spirometry. ${ }^{12}$ The issue of COPD under-diagnosis may be further exacerbated by failure to recognize GOLD Group $C$ patients. These patients are not particularly symptomatic but do experience a substantial number of chest infections. ${ }^{8}$ They, therefore, often remain under the care of their family physician and never receive specialist referral. These issues represent significant hurdles to optimized COPD management in primary care, since establishing and acting on an early diagnosis of COPD is a critical step in reducing the extensive morbidity and mortality of this disease. Large-scale efforts to promote awareness of COPD and encourage early diagnosis have been undertaken, to tackle these issues and others in COPD management (e.g., the National Lung Health Education Program in the United States.). Patient-related hurdles to optimized COPD management include disease denial (lack of understanding, under-estimation of disease impact), poor adherence, lack of patient engagement and empowerment, variable disease presenting patterns, and cost-related issues. ${ }^{12}$

In order to improve the management of COPD 
in primary care, it is first necessary to describe the patient population in a standardized way, using variables which are clinically relevant, and which can be practically collected and monitored longitudinally. This information should be relevant to both physicians and patients to encourage therapeutic, shared decision-making and ultimately better adherence. A COPD registry is one way to achieve these aims. Registries are well-established tools for tracking and reporting epidemiological disease trends, treatment benefits and risks that can be longitudinally monitored. They are also useful to track the natural progression of disease, which may be particularly relevant in COPD where progression is slow, and patterns can be difficult to spot. They have the potential to improve diagnostics and be used to inform treatment algorithms. ${ }^{13}$ Although both national and regional COPD registries and patient cohorts do already exist in the United States, (e.g., the COPD Genetic Epidemiology study ${ }^{14}$ the COPD Patient-Powered Research Network, ${ }^{15}$ and others hosted by universities and health care networks), none are based in primary care. Those based in secondary care focus on patients with more severe disease, missing the milder and moderate severity patients. None have captured information on how patients are managed in primary care in real life.

The Advancing the Patient Experience in COPD (APEX COPD) registry (https://www.apexcopd.org/) will be the first U.S. primary care health systembased registry, designed to follow these patients longitudinally, investigate how they are managed in real-life settings and the consequence(s) of various management strategies. The overall aim is to improve primary care for patients with a diagnosis of COPD by capturing clinically-relevant and high-quality data using a standardized set of variables, from multiple sources, in sufficient numbers of patients to ensure representativeness to the wider COPD population, and to answer key research questions relating to COPD in primary care. The registry plans to bring together information captured in electronic health records (EHRs), and information provided by patients themselves (i.e., from questionnaires and during office visits). This will be achieved using standardized data collection, guided by COPD clinicians both in primary and specialist care. Further, the registry may identify patterns of health care before a diagnosis, ${ }^{16}$ and has the potential to identify new COPD phenotypes.
The aim of the Delphi exercise described in this article was to gain expert consensus on a standardized list of variables on demographic, disease monitoring and treatment variables to establish the APEX COPD registry. Selection of these variables was dictated not only by clinical relevance; it was also important that variables were already known to family physicians and that it was practical and feasible to collect them in primary care.

\section{Methods}

\section{Design}

This study used a modified, 3-round Delphi process to achieve consensus on the core variables to be collected in the APEX COPD registry. ${ }^{17}$ Variables were initially selected from relevant COPD guidelines and recommendations to give all potentially clinically relevant options, and subsequently refined by the panel to the items desired for inclusion in the registry.

\section{Panel Selection}

The APEX COPD Delphi panel consisted of appropriately qualified and experienced individuals in the field of COPD and primary care, capable of providing critical and informed input. This panel included 14 experts in primary and specialist care from the United States and internationally - 5 family physicians, 3 pulmonologists, 6 respiratory researchers (5 of whom had substantial prior experience as family physicians), with $>70 \%$ of panel members based in the United States. (Table E1 in the online supplement). The panel members met 2 or more of the following criteria:

1. Evidence of relevant COPD research published in high-ranking peer-reviewed journals (e.g., high number of citations and research items).

2. A history of participation in the development and/or management of 1 or more respiratory registries or cohorts, epidemiological databases, and scientific congress committees in a country and/or internationally.

3. Experience as a medical clinician (e.g., physician or nurse) with an interest in advancing COPD management in clinical practice.

\section{Modified Delphi Process}

A modified Delphi process was used to reach consensus on which data to collect into the registry 
from EHRs, patient-reported information/patientreported outcomes (PRI/PROs), and at consultation. ${ }^{18}$ The process consisted of 3 iterative rounds (Round 1 [R1], Round 2 [R2] and Round 3 [R3]; Figure 1).

Each Delphi panel member was issued an electronic APEX COPD Excel workbook to review, provide suggestions and vote, to select core variables. Members then returned the completed Delphi workbooks to the APEX COPD administrator within a 4-week time period. The Delphi administrator directly corresponded with all panel members individually to ensure anonymity of replies and was responsible for disseminating workbooks and result summaries for each round.

\section{Delphi Round 1}

The Delphi workbook (APEX COPD Workbook R1) was developed initially by consolidating variables from current guidelines and recommendations: the American Thoracic Society (ATS) and European Respiratory Society (ERS) joint guidelines, the COPD Foundation guidelines, and GOLD. ${ }^{19-26}$ Variables under consideration included:

- Patient demographics.

- Medical history, symptoms (COPD-relevant), prior exacerbations, exposure, and comorbidities.

\section{Figure 1. General Flow of the Advancing the Patient Experience in COPD Registry Delphi Process}

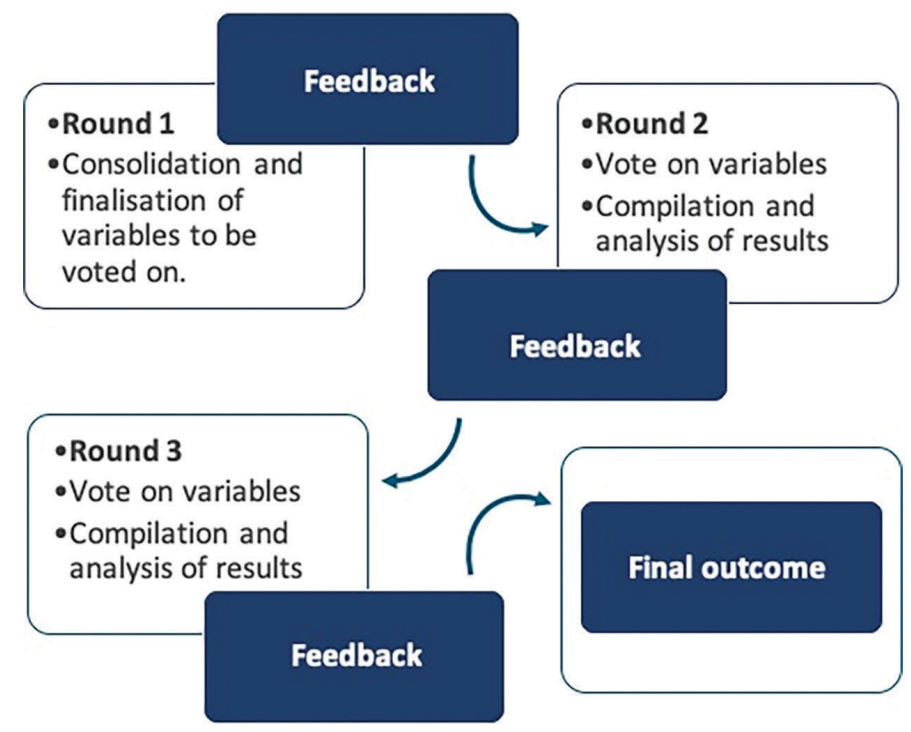

- COPD treatment and management, including medications and side effects (such as those related to steroid exposure and/or biologics), adherence data when available, vaccinations, referrals, surgery, rehabilitation, smoking cessation, and other non-pharmacological strategies.

- Patient-reported information and outcomes including health status scores (COPD Assessment Test, modified Medical Research Council dyspnea scale $[\mathrm{mMRC}]$ ), and questionnaires (e.g., inhaler satisfaction questionnaire, and the Test of Adherence to Inhalers questionnaire) to measure respiratory inhaler device satisfaction and adherence.

- Medical test/investigations, including spirometry, electrocardiogram, and biomarkers (blood eosinophils, immunoglobulin $\mathrm{E}$, and fractional exhaled nitric oxide where possible).

The workbook comprised a 2-tab Excel spreadsheet:

- On tab one, displaying the potential core list (Figure 2), panel members were required to select an option ("Yes" or "No") via a drop-down menu for each variable, indicating whether or not they concurred that the variable would be part of the APEX COPD registry core variables list.

- On tab 2, panel members were encouraged to nominate variables from the "Additional" variables list (Figure 3) and/or propose new variables ("Suggested"). During this round, experts were also encouraged to provide comments for excluding or including variables.

At round closure, the Delphi administrator anonymized all returned workbooks and compiled all replies to tabulate frequency of responses, "Yes" and "No," for each variable on the lists. Variable consensus was evaluated using summary statistics (frequency counts) generated with the Microsoft Excel V16.27 statistical package. Delphi R1 consensus rules for each variable assessed by the panel were as follows: Keep (>66\% “yes"); undecided ( $250 \%$ to $\leq 66 \%$ "yes"); exclude (<50\% “yes").

\section{Delphi Round 2}

All variables from R1 as well as "suggested" variables were included in a single tab in the R2 workbook and the expert panel was requested to engage in a similar voting process for Delphi R2. The Delphi R1 summary 


\section{Figure 2. Sample of the Potential Core Variables List from the Advancing the Patient Experience COPD Registry Delphi Workbook Round 1}

\begin{tabular}{|c|c|c|c|c|c|c|c|c|c|c|c|c|c|}
\hline \multirow[b]{2}{*}{$\begin{array}{l}\text { Should this variable be } \\
\text { included? } \\
\text { (please select yes/no } \\
\text { from drop-down menu in } \\
\text { each cell) }\end{array}$} & \multirow[b]{2}{*}{ Category } & \multirow[b]{2}{*}{ Variable } & \multicolumn{5}{|c|}{$\begin{array}{c}\text { Variable inclusion in prominent COPD templates } \\
\text { and guidelines }\end{array}$} & \multirow[b]{2}{*}{ Entry format } & \multirow[b]{2}{*}{$\begin{array}{c}\text { Response } \\
\text { options }\end{array}$} & \multicolumn{2}{|c|}{ Template auto populated by: } & \multirow[b]{2}{*}{$\begin{array}{l}\text { Entered } \\
\text { at initial } \\
\text { consult }\end{array}$} & \multirow[b]{2}{*}{$\begin{array}{l}\text { Entered } \\
\text { annually }\end{array}$} \\
\hline & & & $\begin{array}{l}\text { GOLD } \\
2018\end{array}$ & $\begin{array}{l}\text { ERS/ATS } \\
2004, \\
2007 \\
2011 \\
2017\end{array}$ & $\begin{array}{l}\text { COPD } \\
\text { Foundation } \\
\text { Guide } 2013\end{array}$ & $\begin{array}{c}\text { OPC UK } \\
\text { (template } \\
\text { and PRO) }\end{array}$ & $\begin{array}{c}\text { COPDX } \\
2018 \\
\text { (Australia) }\end{array}$ & & & $\begin{array}{l}\text { Electronic } \\
\text { Health Record } \\
\text { (EHR) }\end{array}$ & $\begin{array}{c}\text { Patient } \\
\text { questionnaire }\end{array}$ & & \\
\hline & Demographics & Height (In) & $v$ & $\checkmark$ & $\checkmark$ & v & $\checkmark$ & Numeric & Numeric & $\sqrt{2}$ & & $\sqrt{2}$ & v \\
\hline & & Weight (Lb) & $\checkmark$ & $v$ & & $\checkmark$ & $v$ & Numeric & Numeric & $\checkmark$ & & $\checkmark$ & $\checkmark$ \\
\hline & & Biological sex & $\checkmark$ & $\checkmark$ & $\checkmark$ & $\checkmark$ & $\checkmark$ & Drop-down & Male/Female & $\checkmark$ & & $\checkmark$ & \\
\hline & & Age (Yrs) & $\checkmark$ & $\checkmark$ & $v$ & $\checkmark$ & $\checkmark$ & Numeric & Numeric & $\checkmark$ & & $\checkmark$ & \\
\hline & $\begin{array}{l}\text { Physiological } \\
\text { measurements }\end{array}$ & $\begin{array}{l}\text { Predicted FEV1 } \\
\text { (Autocalculated) }\end{array}$ & $\checkmark$ & & & $\checkmark$ & $\checkmark$ & Autocalculated & Numeric & $\checkmark$ & & $\checkmark$ & $\checkmark$ \\
\hline & & $\begin{array}{l}\text { FEV1 pre- } \\
\text { bronchodilator }\end{array}$ & v & & & $\checkmark$ & $\checkmark$ & Numeric & Numeric & $\checkmark$ & & $\checkmark$ & $\checkmark$ \\
\hline & & $\begin{array}{l}\text { FEV1 post- } \\
\text { bronchodilator }\end{array}$ & $\checkmark$ & $\checkmark$ & $\checkmark$ & $\checkmark$ & $\checkmark$ & Numeric & Numeric & $\checkmark$ & & $\checkmark$ & $\checkmark$ \\
\hline & & $\begin{array}{l}\text { FEV1 (pre- } \\
\text { bronchodilator)/Pr } \\
\text { edicted FEV1 } \\
\text { (Autocalculated) }\end{array}$ & $\checkmark$ & & & $\checkmark$ & $\checkmark$ & Autocalculated & Numeric & $\checkmark$ & & $\checkmark$ & $\checkmark$ \\
\hline
\end{tabular}

GOLD=Global initiative for chronic Obstructive Lung Disease; ERS=European Respiratory Society; ATS=American Thoracic Society; $\mathrm{COPD}=$ chronic obstructive pulmonary disease; OPC=Optimum Patient Care; $\mathrm{PRO}=$ patient-reported outcome; COPDX=COPD-X Australian and New Zealand Guidelines; $\mathrm{FEV}_{1}=$ forced expiratory volume in 1 second

\section{Figure 3. Sample of the Additional Variables List from the Advancing the Patient Experience COPD Registry Delphi Workbook Round 1}

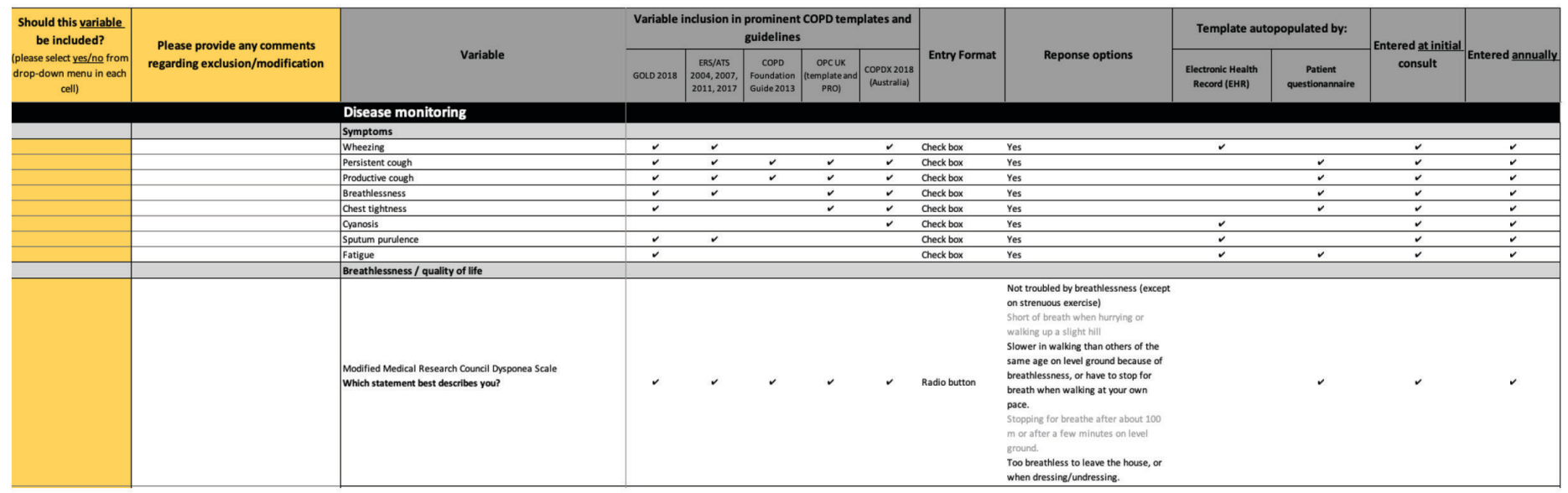

GOLD=Global initiative for chronic Obstructive Lung Disease; ERS=European Respiratory Society; ATS=American Thoracic Society; $\mathrm{COPD}=$ chronic obstructive pulmonary disease; OPC=Optimum Patient Care; $\mathrm{PRO}=$ patient-reported outcome; $\mathrm{COPDX}=\mathrm{COPD}-\mathrm{X}$ Australian and New Zealand Guidelines

results and panel member comments ("Comments") were anonymized and provided in the R2 workbook to facilitate an informed decision. Delphi R2 was divided into 2 parts:

- Round 2a: Each variable that received a $66 \%$ or more consensus from the Delphi panel in R2 was moved to a second phase of analysis (R2b). Other variables were excluded from the APEX COPD registry core variable list.
- Round 2b: Variables moved to R2b were analyzed more specifically to determine which data sources they should be collected from (EHRs, PRI/PRO, or at the doctor's office [i.e., point of care (PoC)]).

Delphi R2 consensus rules for each variable assessed by the panel were as follows: Keep ( $\geq 66 \%$ consensus); undecided ( $40 \%$ to $65 \%$ consensus); exclude ( $<40 \%$ consensus). Additionally, all excluded variables from $\mathrm{R} 2$ were vetted by the APEX COPD 
Operational Management Group (AOMG) (Table E2 in the online supplement). If excluded variables were considered key to COPD primary care by the AOMG, they were re-included for review in R3.

\section{Delphi Round 3}

The Delphi panel also took part in a similar voting process for Delphi R3 via a third electronically distributed workbook (The APEX COPD Delphi Workbook R3). The Delphi R2 summary results and panel member comments ("Comments") were anonymized and provided in the $\mathrm{R} 3$ workbook to facilitate an informed decision. R2 "Undecided" and additional AOMG vetted variables were included in the R3 workbook. Delphi R3 consensus rules for each variable assessed by the panel were as follows: keep ( $\geq 66 \%$ consensus); undecided ( $40 \%$ to $65 \%$ consensus); exclude ( $<40 \%$ consensus). All undecided and excluded variables from $\mathrm{R} 3$ were vetted by the $A O M G$. If these variables were considered key to COPD primary care by the AOMG, they were included in the final core variable list.

\section{Results}

\section{Delphi Round 1}

In $\mathrm{R} 1$, the expert panel voted on 189 clinical COPD variables belonging to the categories of demographics, disease monitoring, and treatment (Table E3 in the online supplement). Overall, 149 of the variables received $>66 \%$ consensus to keep, 25 were undecided ( $50 \%$ to $66 \%$ consensus), and 15 were recommended to exclude (receiving $<50 \%$ consensus) (Table E4 in the online supplement). All 189 variables were entered into voting R2. Six "suggested" variables recommended by the panel were also added bringing the total to 195 variables to proceed to R2.

\section{Delphi Round 2}

After voting R2, 25 of the 195 variables were excluded from collection into the registry and 170 were confirmed for collection (Table E5, Part A in the online supplement). The Delphi panel recommended that of the 170 confirmed variables, 115 be collected from EHRs, and 16 via PRI/PRO. At this stage, no variables were confirmed for collection by clinicians during a visit. (Table E5, Part B in the online supplement). Undecided variables were entered into Delphi R3. Four undecided PRI/PRO variables from
R2a were re-included for review in R3. These were:

- Poor appetite: an important factor used in conjunction with other cancer indicators which received consensus votes to be included for collection.

- Easy bruising: specific types of physiological side effects were not specified for voting; bruising is a common and important side effect to assess in patients receiving inhaled corticosteroids (ICSs).

- Pain (headache and muscle): specific types of pain as side effects were not specified for voting; muscle pain and headaches are common and preventable effects to assess in patients receiving inhaled medications.

- Low birth weight: an important childhood risk factor which may not be recorded in patients' EHRs.

One excluded PoC variable from R2a was re-included for review in R3. This was:

- Inhaler technique assessment: important for interpretation of peak inspiratory flow rate (PIFR) which received a consensus vote to be included for collection from the EHR and an undecided vote to be collected during the office visit.

\section{Delphi Round 3}

A final round of voting (R3) was undertaken to vote on "undecided" PRI/PRO and PoC variables from R2. A total of $13 \mathrm{PRI} / \mathrm{PRO}$ and 2 PoC variables were kept on consensus. Of the remaining 27 undecided $\mathrm{PRI} / \mathrm{PRO}$ variables at $\mathrm{R} 3$, a total of 3 were confirmed for collection by the AOMG (Table E6 in the online supplement). The reasons were:

- Pulmonary rehabilitation: critical for prevention of disease progression and management.

- Influenza vaccine: can be administered by an external provider and therefore may not be collected in patients' EHRs. This information is critical for informing preventative care.

- Oral treatment side effect (candidiasis): specific types of oral side effects not specified for voting; oral candidiasis is a common and important side effect to assess in patients receiving ICSs.

Two additional PRI/PRO variables excluded in $\mathrm{R} 2 \mathrm{~b}$ were vetted and included in the final core variable 
list. These were:

- Asthma diagnosis (age of onset): decision to collect via PRI/PRO in addition to the EHR to identify age of onset where this information is unavailable in the EHR.

- Physiological treatment side effect (easy bruising): specific types of physiological side effects were not specified for voting; bruising is a common and important side effect to assess in patients receiving ICSs.

Of the 3 undecided variables for collection during the office visit at R3, all were confirmed for collection by the AOMG. These were:

- Number of severe exacerbations in the past year,

- Forced expiratory volume in one second $\left(F_{E V}\right)$ post-bronchodilator, and

- Forced vital capacity (FVC) post-bronchodilator

These were all considered critical for COPD management and will be collected at PoC only if missing from the EHR and PRI/PRO.

The core variables that achieved consensus via the closely guided 3 rounds of Delphi were included in the final core variable list and their importance described (Table 1). 8,22,27-31

\section{Discussion}

Using the knowledge and experience of an international panel of COPD experts, workable criteria for registry purposes, a standardized core set of variables, and a potential method to unify data for COPD in the United States were generated and agreed to by consensus. All potential variables underwent a rigorous, stepwise consensus process to ensure the collection of the minimum required information to effectively and practically study the diagnosis and management of patients with COPD. Of the initially circulated "potential core" and "suggested" variables, 115 variables from existing EHRs, 34 PRI/PRO variables and 5 variables to be collected during office visits, were selected for integration into the APEX COPD registry (Figure 4). These selected variables fall into 3 broad categories (i.e., demographics, disease monitoring, and treatment), and should include information on diagnosis, exacerbations, symptoms, lung function and quality of life, comorbidities, smoking history, treatment specifics (including side effects), inhaler management (including inhaler technique) and education/self-management. They have been selected not only due to their clinical relevance and usefulness to family doctors and patients (Table 1) but also with feasibility, familiarity and practicality of collection in mind. This will ensure that the APEX COPD registry will be an asset to family doctors; a tool to identify how patients with COPD are managed in real life, in a population rarely included in randomized controlled trials. Following ratification of data collection, the registry plans to integrate information from multiple sources with maximal efficiency and present it to clinicians and patients in a structured and clinically useful format, with the aim of improving primary care for patients diagnosed with COPD. Data from the registry will also be used to answer key research questions relating to COPD in primary care, facilitating insight into this prevalent chronic disease. The outcomes of such research and any new research proposals will be continuously updated via the APEX COPD website (https://www.apexcopd.org/).

The panel-approved APEX COPD registry variables were chosen to ensure a comprehensive description of patients diagnosed with COPD and managed in real-life clinical practice among family physicians in the United States. Collection of baseline information on diagnosis, infection, exacerbations, severity classification, health status, and treatment-/comorbidity-patterns will provide a snapshot of clinical phenotypes of COPD, a better understanding of how patients are diagnosed and managed in primary care (e.g., use of spirometry), an estimation of the burden of disease (including the corticosteroid burden), and an assessment of whether diagnoses and severity classifications are correct and treatment is appropriate (compared to guideline recommendations). ${ }^{8}$ Appropriate variables will be assessed longitudinally to examine their impact on disease progression and treatment outcomes. For example, data may be assessed to: (1) compare the clinical, safety and cost-effectiveness of current COPD treatments; (2) describe treatment changes over time (and the reasons for those changes); (3) assess the impact of inhaler technique and inhaler type on key outcomes; (4) analyze risk factors associated with disease progression and health care utilization; and 


\section{Table 1. Final Core Variable List to be Collected from the Electronic Health Record, Patient-Reported Information and Outcomes, and at the Point of Care}

\begin{tabular}{|c|c|c|c|}
\hline Category $^{a}$ & Sub-category & Variable & Why is it important to collect? \\
\hline & & \multicolumn{2}{|l|}{ Electronic Health Record Variables $(n=115)$} \\
\hline \multirow[t]{6}{*}{ Demographics } & & Height (In) & \multirow{2}{*}{$\begin{array}{l}\text { Required to predict lung function } \\
\text { parameters. }\end{array}$} \\
\hline & & Weight (lb) & \\
\hline & & Biological Sex & \multirow{4}{*}{$\begin{array}{l}\text { Women and some ethnicities have smaller } \\
\text { lungs, so these data could prospectively } \\
\text { show risk of COPD at different smoking } \\
\text { rates etc. }\end{array}$} \\
\hline & & Age (yrs) & \\
\hline & & BMI & \\
\hline & & Race & \\
\hline \multirow{24}{*}{$\begin{array}{l}\text { Disease } \\
\text { Monitoring }\end{array}$} & $C O P D$ & COPD & \multirow{4}{*}{$\begin{array}{l}\text { These are different phenotypes of COPD and } \\
\text { when available should be captured } \\
\text { separately. }\end{array}$} \\
\hline & \multirow{3}{*}{ Diagnosis } & Chronic Bronchitis & \\
\hline & & Emphysema & \\
\hline & & AATD & \\
\hline & $\begin{array}{l}\text { Differential } \\
\text { Diagnosis }\end{array}$ & Asthma & $\begin{array}{l}\text { Asthma is the most common differential } \\
\text { diagnosis and often co-exists with COPD } \\
\text { (i.e., ACOS). } \\
\text { GOLD recommendation to identify and } \\
\text { appropriately manage. }{ }^{8}\end{array}$ \\
\hline & \multirow[t]{2}{*}{$\begin{array}{l}\text { Respiratory } \\
\text { Infection }\end{array}$} & $\begin{array}{l}\text { Number of pneumonia infections in } \\
\text { past } 2 \mathrm{yrs}\end{array}$ & $\begin{array}{l}\text { May be indicators of unrecognized COPD } \\
\text { exacerbations. }\end{array}$ \\
\hline & & Number of other RTIs in past 2 yrs & $\begin{array}{l}\text { May be side effect of ICSs used in COPD } \\
\text { management. }\end{array}$ \\
\hline & \multirow[t]{2}{*}{ Exacerbations } & $\begin{array}{l}\text { Number of moderate exacerbations in } \\
\text { past year (also indicated by short } \\
\text { course of Atb or OCS) }\end{array}$ & $\begin{array}{l}\text { Necessary to characterize severity, assess } \\
\text { treatment effectiveness and monitor disease } \\
\text { progression. }\end{array}$ \\
\hline & & $\begin{array}{l}\text { Number of severe exacerbations in past } \\
\text { year (also indicated by hospitalization } \\
\text { and course of Atb/OCS) }\end{array}$ & $\begin{array}{l}\text { May indicate a need for treatment escalation } \\
\text { or treatment switch if the disease is poorly } \\
\text { controlled. }\end{array}$ \\
\hline & Symptoms & Wheezing & $\begin{array}{l}\text { The most common symptom of COPD, after } \\
\text { dyspnea. }\end{array}$ \\
\hline & \multirow{14}{*}{ Measurements } & Predicted $\mathrm{FEV}_{1}$ (auto-calculated) & \multirow{2}{*}{$\begin{array}{l}\mathrm{FEV}_{1} / \mathrm{FVC} \text { post bronchodilator necessary } \\
\text { for COPD diagnosis. }\end{array}$} \\
\hline & & $\mathrm{FEV}_{1}$ pre-bronchodilator & \\
\hline & & FEV 1 post-bronchodilator & \multirow{2}{*}{$\begin{array}{l}\mathrm{FEV} V_{1} \text { provides information on severity of } \\
\text { lung function impairment. }\end{array}$} \\
\hline & & $\mathrm{FEV}_{1}$ (pre-bronchodilator)/Predicted & \\
\hline & & $\mathrm{FEV}_{1}$ (auto-calculated) & \multirow{2}{*}{$\begin{array}{l}\text { Reversibility indicates the possibility of } \\
\text { comorbid asthma. }\end{array}$} \\
\hline & & Predicted FVC (auto-calculated) & \\
\hline & & FVC pre-bronchodilator & FVC indicates restrictive issues. \\
\hline & & FVC post-bronchodilator & \multirow{2}{*}{$\begin{array}{l}\text { Oxygenation falls later in the disease. But } \\
\text { treating with oxygen is the only medication } \\
\text { that affects prognosis. }\end{array}$} \\
\hline & & $\begin{array}{l}\mathrm{FVC} \text { (pre-bronchodilator)/Predicted FVC } \\
\text { (auto-calculated) }\end{array}$ & \\
\hline & & $\begin{array}{l}\text { Predicted } \mathrm{FEV}_{1} / \mathrm{FVC} \text { ratio } \\
\text { (auto-calculated) }\end{array}$ & $\begin{array}{l}\text { Blood eosinophilia a useful predictor of ICS } \\
\text { response. }\end{array}$ \\
\hline & & \multirow{2}{*}{$\begin{array}{l}\mathrm{FEV}_{1} / \mathrm{FVC} \text { pre-bronchodilator } \\
\text { (auto-calculated) }\end{array}$} & \multirow{3}{*}{$\begin{array}{l}\text { CXR: useful for comorbidity assessment. } \\
\text { CT: necessary for bronchiectasis and lung } \\
\text { cancer screening. }\end{array}$} \\
\hline & & & \\
\hline & & $\mathrm{FEV}_{1} / \mathrm{FVC}$ post-bronchodilator & \\
\hline & & (auto-calculated) & $\mathrm{CV}$ disease (and $\mathrm{BP}$ ) is the major comorbidity. \\
\hline
\end{tabular}




\begin{tabular}{|c|c|c|c|}
\hline Category $^{a}$ & Sub-category & Variable & Why is it important to collect? \\
\hline
\end{tabular}

\begin{tabular}{|c|c|c|c|}
\hline & & Reversibility (\%) & \\
\hline & & PIFR & \\
\hline & & Pulse Oximetry $\left(\mathrm{SpO}_{2}, \%\right)$ & \\
\hline & & Full Blood Count & \\
\hline & & Blood Eosinophil Count & \\
\hline & & Chest X-ray & \\
\hline & & CT Scan & \\
\hline & & Systolic BP (mm Hg) & \\
\hline & & Diastolic BP (mm Hg) & \\
\hline & & 6-minute Walking Test (ft) & \\
\hline & GOLD & GOLD 1-4 (auto-calculated) & To assess appropriateness of severity \\
\hline & Categorization & GOLD A-D (auto-calculated) & $\begin{array}{l}\text { classification and its impact on disease and } \\
\text { treatment outcomes. }\end{array}$ \\
\hline & Differential & Allergy & Comorbidities most likely associated with \\
\hline & Diagnosis & Rhinitis & asthma. \\
\hline & (predicting & Nasal Polyps & Sinusitis is related to infectious risk. \\
\hline & asthma) & Eczema & \\
\hline & & Sinusitis & \\
\hline & Differential & Ankle Edema & Signs of left and or right heart failure. \\
\hline & Diagnosis & Echocardiogram & \\
\hline & $\begin{array}{l}\text { (predicting } \\
\text { heart failure) }\end{array}$ & Elevated B-type Natriuretic Peptide & \\
\hline & Differential & Weight Loss & TB differential diagnosis. \\
\hline & $\begin{array}{l}\text { Diagnosis } \\
\text { (predicting } \\
\text { lung cancer) }\end{array}$ & Hemoptysis & \\
\hline & Other & Pneumonia & A serious comorbidity to COPD. \\
\hline & $\begin{array}{l}\text { Differential } \\
\text { Diagnosis }\end{array}$ & & $\begin{array}{l}\text { A potential side effect of ICS use in COPD } \\
\text { management. }\end{array}$ \\
\hline & Comorbidities & Angina Pectoris/Heart Disease/CHD & May require further evaluation/investigation. \\
\hline & (cardiovascular) & Heart Failure & $\overline{\text { May affect outcomes. }}$ \\
\hline & & Stroke & CHF also presents with dyspnea and is not \\
\hline & & Hypertensive Disease & always easy to tell apart. \\
\hline & Comorbidities & Lung Cancer & May significantly impact quality of life. \\
\hline & (pulmonary) & Obstructive Sleep Apnea & \\
\hline & & Hypoxemia & \\
\hline & Comorbidities & Diabetes Mellitus & \\
\hline & (endocrinological) & Osteoporosis & \\
\hline & & Osteoarthritis & \\
\hline & & Metabolic Syndrome & \\
\hline & Comorbidities & Depression & \\
\hline & (mental) & Anxiety & \\
\hline & Comorbidities & GERD & \\
\hline & (other) & Anemia & \\
\hline Treatment & Bronchodilators & SABA & Required to: \\
\hline and & & LABA & Characterize treatments used. \\
\hline & & SAMA & Assess frequency of use. \\
\hline & & LAMA & Assess appropriateness of treatment \\
\hline & Steroids & ICS & selection. \\
\hline
\end{tabular}




\begin{tabular}{|c|c|c|c|}
\hline Category $^{a}$ & | Sub-category & Variable & Why is it important to collect? \\
\hline & Steroids & OCS & \multirow{2}{*}{$\begin{array}{l}\text { Assess effectiveness of treatments and } \\
\text { regimens (e.g., dual vs triple). }\end{array}$} \\
\hline & \multirow[t]{5}{*}{ Combinations } & SABA/SAMA & \\
\hline & & LABA/LAMA & Assess ICS over use. \\
\hline & & ICS/LAMA & Assess OCS burden. \\
\hline & & ICS/LABA & Assess impact of inhaler choice. \\
\hline & & ICS/LAMA/LABA & \\
\hline & \multirow{4}{*}{$\begin{array}{l}\text { Comorbidity } \\
\text { Treatments }\end{array}$} & Heart Failure & \multirow[t]{4}{*}{ To assess their impact on prognosis. } \\
\hline & & Diabetes & \\
\hline & & Osteoporosis & \\
\hline & & Asthma & \\
\hline & \multirow{7}{*}{$\begin{array}{l}\text { Other } \\
\text { Treatments }\end{array}$} & Antibiotics & \multirow{7}{*}{$\begin{array}{l}\text { To evaluate effectiveness and exacerbation } \\
\text { risk reduction. }\end{array}$} \\
\hline & & Macrolides & \\
\hline & & PDE Inhibitors & \\
\hline & & Methylxanthines (e.g., theophylline) & \\
\hline & & LTRA & \\
\hline & & Diuretics & \\
\hline & & Mucolytics & \\
\hline & \multirow{3}{*}{$\begin{array}{l}\text { Smoking } \\
\text { (cigarettes) }\end{array}$} & Smoking Status & \multirow[t]{3}{*}{ The most common etiology. } \\
\hline & & How many years has patient smoked? & \\
\hline & & Pack Years & \\
\hline & \multirow[t]{2}{*}{ Vaccinations } & Influenza & \multirow{2}{*}{$\begin{array}{l}\text { Key preventative vaccinations. Decrease the } \\
\text { risk of LTRI. }{ }^{8}\end{array}$} \\
\hline & & Pneumococcal (both) & \\
\hline & \multirow{4}{*}{$\begin{array}{l}\text { Smoking } \\
\text { Cessation }\end{array}$} & Smoking cessation advice given & \multirow{2}{*}{$\begin{array}{l}\text { To assess prognosis \& determine which } \\
\text { works best. }\end{array}$} \\
\hline & & Referral to stop-smoking clinic/advisor & \\
\hline & & Nicotine replacement therapy & \multirow[b]{2}{*}{$\begin{array}{l}\text { Has the greatest capacity to influence the } \\
\text { natural history of COPD. GOLD } \\
\text { recommends to collect in order to monitor } \\
\text { and encourage appropriate cessation } \\
\text { interventions. } 8\end{array}$} \\
\hline & & Drug Therapy (e.g., Bupropion) & \\
\hline & \multirow[t]{6}{*}{ Surgery } & Bullectomy & \multirow{6}{*}{$\begin{array}{l}\text { To identify best candidates and outcome for } \\
\text { each of these surgical interventions. }\end{array}$} \\
\hline & & Lung Volume Reduction Surgery & \\
\hline & & Lung Volume Reduction Coil & \\
\hline & & Endobronchial Valve & \\
\hline & & Lung Transplant & \\
\hline & & Chest Wall Vibration & \\
\hline & \multirow{9}{*}{$\begin{array}{l}\text { Specialist } \\
\text { Referral }\end{array}$} & Palliative Care & \multirow{9}{*}{$\begin{array}{l}\text { To consider respiratory evaluations by } \\
\text { non-respiratory or primary care doctors. }\end{array}$} \\
\hline & & Physiotherapist & \\
\hline & & Occupational Therapist & \\
\hline & & Speech Therapist & \\
\hline & & Clinical Psychiatrist & \\
\hline & & Clinical Psychologist & \\
\hline & & Dietitian & \\
\hline & & Exercise Physiologist & \\
\hline & & Chest Physician & \\
\hline & \multirow{4}{*}{$\begin{array}{l}\text { Other } \\
\text { Therapies }\end{array}$} & Pulmonary Rehabilitation & To assess availability and efficacy. \\
\hline & & Oxygen Therapy & \multirow[t]{3}{*}{$\mathrm{PR}$ is critically important for best outcomes. } \\
\hline & & Home Nebulizer & \\
\hline & & Ventilatory Support & \\
\hline
\end{tabular}




\begin{tabular}{|c|c|c|c|}
\hline Category $^{a}$ & Sub-category & Variable & Why is it important to collect? \\
\hline & & \multicolumn{2}{|c|}{ Patient-Reported Information/Patient-Reported Outcome Variables (n=34) } \\
\hline \multirow{19}{*}{$\begin{array}{l}\text { Disease } \\
\text { Monitoring }\end{array}$} & \multirow{3}{*}{$\begin{array}{l}\text { Differential } \\
\text { Diagnosis }\end{array}$} & \multirow[t]{3}{*}{ Asthma } & Asthma is the most common differential \\
\hline & & & $\begin{array}{l}\text { diagnosis and often co-exists with COPD } \\
\text { (i.e., ACOS). }\end{array}$ \\
\hline & & & $\begin{array}{l}\text { GOLD recommendation to identify and } \\
\text { manage appropriately. }{ }^{8}\end{array}$ \\
\hline & \multirow{3}{*}{$\begin{array}{l}\text { Respiratory } \\
\text { Infections }\end{array}$} & \multirow{2}{*}{$\begin{array}{l}\text { Number of pneumonia infections in } \\
\text { past } 2 \text { yrs }\end{array}$} & Effect on disease outcome \\
\hline & & & \multirow[t]{2}{*}{ Effect on treatment outcome } \\
\hline & & Number of other RTIs in past 2 yrs & \\
\hline & \multirow[t]{3}{*}{ Exacerbations } & \multirow{2}{*}{$\begin{array}{l}\text { Number of moderate exacerbations in } \\
\text { past year (also indicated by course of } \\
\text { Atb/OCS) }\end{array}$} & Key patient outcome. \\
\hline & & & $\begin{array}{l}\text { Indicator of severity, disease progression } \\
\text { and effectiveness of treatment. }\end{array}$ \\
\hline & & $\begin{array}{l}\text { Number of severe exacerbations in past } \\
\text { year (also indicated by emergency } \\
\text { hospitalization and course of Atb/OCS) }\end{array}$ & $\begin{array}{l}\text { Indication of a need for treatment escalation } \\
\text { or treatment switch. }\end{array}$ \\
\hline & \multirow{2}{*}{$\begin{array}{l}\text { Health } \\
\text { Status } \\
(Q o L) \\
\end{array}$} & mMRC Dyspnea Scale & Key patient outcome (validated scales). \\
\hline & & COPD Assessment Test & $\begin{array}{l}\text { Indicator of severity, disease progression } \\
\text { and effectiveness of treatment. }{ }^{27}\end{array}$ \\
\hline & \multirow[t]{6}{*}{ Risk Factors } & Childhood Respiratory Infections & \multirow{2}{*}{$\begin{array}{l}\text { Little- and well-known risk factors for } \\
\text { COPD development. }\end{array}$} \\
\hline & & Occupational Exposure & \\
\hline & & Tobacco Exposure & \multirow{4}{*}{$\begin{array}{l}\text { History of severe childhood respiratory } \\
\text { infection has been associated with reduced } \\
\text { lung function and increased respiratory } \\
\text { symptoms in adulthood. }{ }^{28}\end{array}$} \\
\hline & & Age of Onset of Respiratory & \\
\hline & & Symptoms yrs & \\
\hline & & Family History of COPD & \\
\hline & \multirow{2}{*}{$\begin{array}{l}\text { Comorbidities } \\
\text { (mental) }\end{array}$} & Depression & \multirow{2}{*}{$\begin{array}{l}\text { Prognostic outcomes and indicators of } \\
\text { quality of life. }\end{array}$} \\
\hline & & Anxiety & \\
\hline \multirow{20}{*}{$\begin{array}{l}\text { Treatment } \\
\text { and } \\
\text { Management }\end{array}$} & \multirow{5}{*}{$\begin{array}{l}\text { Inhaler } \\
\text { Management }\end{array}$} & Spacer with MDI & \multirow{2}{*}{$\begin{array}{l}\text { Good inhaler technique is critical to get } \\
\text { medication where it is needed. }\end{array}$} \\
\hline & & Inhaler Technique Training & \\
\hline & & Inhaler Use/Adherence & \multirow{2}{*}{$\begin{array}{l}\text { Poor technique and poor adherence are } \\
\text { commonly associated with poor symptom } \\
\text { control in COPD. }{ }^{29}\end{array}$} \\
\hline & & $\begin{array}{l}\text { Test of Adherence to Inhalers } \\
\text { Questionnaire }\end{array}$ & \\
\hline & & Inhaler Satisfaction Questionnaire & $\begin{array}{l}\text { Patient satisfaction and preference are often } \\
\text { not collected. Patient satisfaction with } \\
\text { treatment may influence adherence. }{ }^{30}\end{array}$ \\
\hline & \multirow{3}{*}{$\begin{array}{l}\text { Treatment } \\
\text { Side } \\
\text { Effects }\end{array}$} & Oral & \multirow{3}{*}{$\begin{array}{l}\text { An important patient outcome which may } \\
\text { impact treatment adherence and } \\
\text { continuance. }\end{array}$} \\
\hline & & Physiological & \\
\hline & & & \\
\hline & \multirow[t]{5}{*}{ Smoking } & Smoking Status & \multirow[t]{5}{*}{ Important for prognosis. } \\
\hline & & Date Ceased Smoking (if applicable) & \\
\hline & & How many cigarettes smoked per day? & \\
\hline & & How many years has patient smoked? & \\
\hline & & Uses E-cigarette? & \\
\hline & Vaccinations & Influenza & A preventable issue. \\
\hline & \multirow{3}{*}{$\begin{array}{l}\text { Smoking } \\
\text { Cessation }\end{array}$} & Desire to quit smoking & To assess motivation to quit. \\
\hline & & Tried to quit in the past & \multirow[t]{2}{*}{ To encourage motivational interviewing. } \\
\hline & & Smoking cessation advice given & \\
\hline & \multirow{3}{*}{$\begin{array}{l}\text { Education and } \\
\text { Self-Management }\end{array}$} & COPD Education & \multirow{2}{*}{$\begin{array}{l}\text { To assess available, utility and the benefits } \\
\text { (if any) of action plans. }\end{array}$} \\
\hline & & COPD Self-management Plan & \\
\hline & & Patient's use of COPD & Education and self-management interventions \\
\hline
\end{tabular}




\begin{tabular}{|c|c|c|c|}
\hline Category $^{a}$ & Sub-category & Variable & Why is it important to collect? \\
\hline & & self-management plan & $\begin{array}{l}\text { can help improve the physical and } \\
\text { psychological condition of COPD patients } \\
\text { and promote long-term adherence to } \\
\text { health-enhancing behaviors. }{ }^{31}\end{array}$ \\
\hline & \multirow{2}{*}{$\begin{array}{l}\text { Other } \\
\text { Therapies }\end{array}$} & Pulmonary Rehabilitation & \multirow{2}{*}{$\begin{array}{l}\text { To assess availability and efficacy. } \\
\text { PR is critically important for best outcomes. }\end{array}$} \\
\hline & & & \\
\hline & & Point of Care Variables $(n=5)$ & \\
\hline \multirow{6}{*}{$\begin{array}{l}\text { Disease } \\
\text { Monitoring }\end{array}$} & \multirow[t]{4}{*}{ Exacerbations } & \multirow{3}{*}{$\begin{array}{l}\text { Number of moderate exacerbations } \\
\text { in past year (also indicated by course } \\
\text { of Atb/OCS) }\end{array}$} & \multirow{4}{*}{$\begin{array}{l}\text { Key patient outcome. } \\
\text { An indicator of severity, disease progression } \\
\text { and effectiveness of treatment. }\end{array}$} \\
\hline & & & \\
\hline & & & \\
\hline & & $\begin{array}{l}\text { Number of severe exacerbations in } \\
\text { past year (also indicated by } \\
\text { emergency hospitalization and } \\
\text { course of Atb/OCS) }\end{array}$ & \\
\hline & \multirow{2}{*}{$\begin{array}{l}\text { Physiological } \\
\text { Measures }\end{array}$} & $\mathrm{FEV}_{1}$ post-bronchodilator & An indicator of illness progression. \\
\hline & & FVC post-bronchodilator & To unmask other illnesses. \\
\hline $\begin{array}{l}\text { Treatment } \\
\text { and } \\
\text { Management }\end{array}$ & $\begin{array}{l}\text { Inhaler } \\
\text { Management }\end{array}$ & Inhaler Technique Assessment & $\begin{array}{l}\text { To assess impact on treatment efficacy and } \\
\text { to better select device if treatment or device } \\
\text { change required. This might include } \\
\text { observed technique and PIFR assessment if } \\
\text { felt clinically necessary. }\end{array}$ \\
\hline
\end{tabular}

*Variables are categorized in this way to simplify Delphi voting. For the purpose of reporting variables may fall into multiple categories

$\mathrm{COPD}=$ chronic obstructive pulmonary disease; $\mathrm{BMI}=$ body mass index; $\mathrm{AATD}=$ alpha- 1 antitrypsin deficiency; $\mathrm{ACOS}=\mathrm{asthma} / \mathrm{COPD}$ overlap syndrome; RTI=respiratory tract infection; ICS=inhaled corticosteroid; Atb=antibiotic; OCS=oral corticosteroid; $F E V_{1}=$ forced expiratory volume in 1 second; $\mathrm{FVC}=$ forced vital capacity; $\mathrm{CXR}=$ chest $\mathrm{X}$-ray; $\mathrm{CT}=$ computed tomography; $\mathrm{CV}=$ cardiovascular; $\mathrm{BP}=\mathrm{blood}$ pressure; PIFR=peak inspiratory flow rate; GOLD=Global initiative for chronic Obstructive Lung Disease; $\mathrm{CHD}=$ coronary heart disease; $\mathrm{CHF}=$ congestive heart failure; GERD=gastroesophageal reflux disease; SABA: short-acting beta2-agonist; LABA=long-acting beta2-agoinist; SAMA=short-acting muscarinic antagonist; LAMA=long-acting muscarinic antagonist; PDE=phosphodiesterase; LTRA=leukotriene receptor antagonist; $\mathrm{mMRC}=$ modified Medical Research Council; MDI=metered dose inhaler; $\mathrm{E}$-cigarette=electronic cigarette

(5) predict response to treatment (e.g., biomarkers).

As well as the collection of key COPD variables from multiple sources, the APEX COPD registry has numerous other assets, including: (1) its size and scope; (2) innovative use of technology to collect high quality data; (3) inclusion of clinical and database management expertise; (4) inclusion of expertise on gathering patient-reported information; (5) an integrated communication strategy; and (6) the organizational structure to oversee the initiative and ensure its continuance. Currently, it is planned to capture information from $3000+$ patients diagnosed with COPD, with a wide geographic coverage throughout the United States, benefiting from both scale and generalizability to the wider COPD population. Patients included will have a diagnostic, monitoring, or review code for COPD prior to or at consultation and be aged $\geq 35$ years at COPD diagnosis. Data collected by the APEX COPD registry will be maintained as a limited dataset in the APEX COPD database. Data will be completely de- identified, at the individual level, and anonymized when providing subsets of data for research purposes. Electronic data capture systems will be utilized to capture data directly from EHRs, which may already include valuable information on symptoms, lung function, COPD staging, pharmacologic treatment, comorbidities, and exacerbations. Use of an existing data resource to populate the APEX COPD registry precludes the need for lengthy additional data collection at the PoC, which will improve efficiency, reduce workload, time, and cost, and enhance the quality of data collected.

Expertise is embedded into the initiative, including the panel of 14 COPD experts on the APEX COPD Steering Committee, recruitment of primary care consultants experienced in COPD management, incorporation of a dedicated communications team to disseminate key research findings and partnership with experts in PRI and PRO (the COPD Foundation and the American Academy of Family Physicians), and database management and registry 


\section{Figure 4. Summary of the Delphi Results for the Advancing the Patient Experience in COPD Registry}

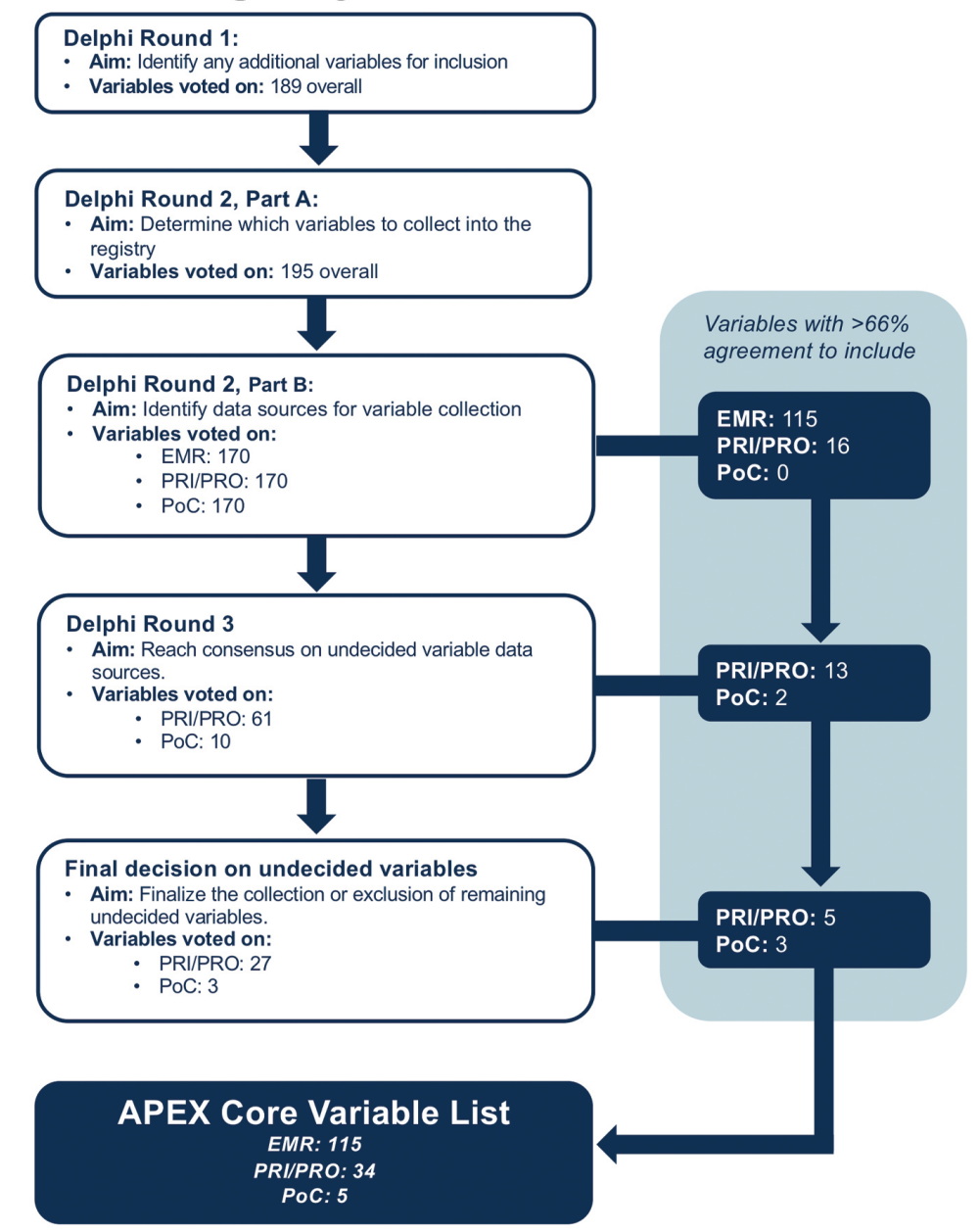

delivery (DARTNet Institute, Aurora, Colorado). Communication of APEX COPD registry research findings will also be facilitated via regular publication in peer-reviewed journals and dissemination of findings at international and regional scientific meetings. The APEX COPD registry is overseen by 5 bodies (Optimum Patient Care Global, the Respiratory Effectiveness Group, the Anonymized Data Ethics and Protocol Transparency Committee, the American Academy of Family Physicians, and the APEX COPD Steering Committee) safeguarding continuance of the registry into the future, and ensuring APEX COPD research is ethical, clinically appropriate and continues to bring genuine value to physicians who manage COPD in real-life clinical practice, and to patients who live with COPD.

\section{Strengths and Weaknesses}

Fourteen Delphi panel members from 4 countries
(>70\% U.S.-based experts) participated in 1 or more Delphi rounds, to allow for broad consensus to be obtained, and to ensure recommendations were pertinent not only to the United States, but also maintained applicability beyond U.S. borders. This approach dilutes the opinion of a single expert, so bias is decreased and diversity within the expert panel is maximized. Panel members were chosen for their expertise in the research field, and relevant medical practice and experience. The anonymity of the survey ensured all opinions were given equal weight and consideration. The Delphi process was carried out online, to facilitate ease of yes/no voting for each variable, as well as rapid and accurate vote counting and classification (i.e., yes, no, undecided) at the end of each Round. It also facilitated rapid and open communication among the COPD experts. The results covered a wide range of areas where consensus was achieved. Although the study employed a relatively 
small Delphi panel, recent studies have found that reliable outcomes can be obtained with a relatively small number of Delphi experts. ${ }^{32}$ The Delphi panel was also not fully representative of the diversity of stakeholders involved in respiratory care at the primary care level. In particular, the opinions of payers and patients were not solicited. Another limitation of the study is that the response rate was not $100 \%$; a total of 13 of 14 experts (93\%) responded to all 3 Delphi rounds. However, there was consistency in the number of experts who participated in each round (R1=93\%; R2=100\%; R3=100\%), which ensured that the possibility of reaching consensus was conserved.

In conclusion, COPD experts have agreed on core variables to collect in the APEX COPD registry. The majority of these variables will be extracted from EHRs but will also include PRI/PRO and PoC data from $3000+$ patients diagnosed with COPD across the United States. Data will be integrated, standardized and stored in the APEX COPD database and made available for COPD-related research. It will be used to analyze COPD natural history as well as clinical, safety and cost-effectiveness of current COPD treatments in primary care across the United States.

\section{Acknowledgments \\ Author contributions:}

CE, LB, VC, and CP contributed to the concept and/or design of this study. Acquisition and analysis of data was provided by CE, MK, CLL and DP. Interpretation of results was provided by CE, AK, BY, JWK, KLC, CF, GG, MH, CM BM, WP AS, NS and DP. All authors have revised each draft, contributed to the intellectual content of the articles and given final approval of the version to be published. All authors agree to be accountable for all aspects of the work, ensuring that questions related to the accuracy or integrity of any part of the work are appropriately investigated and resolved. The authors meet criteria for authorship as recommended by the International Committee of Medical Journal Editors.

We thank Alvaro Aranda, MD, (Hospital Auxilio Mutuo, San Juan, Puerto Rico) for his scientific and clinical contributions during the drafting of this manuscript. We also thank Audrey Ang for editorial assistance, Bronte Sawyer for project coordination, and Lisa Buttle, PhD, for assistance with drafting the article. Ruth B. Murray, PhD is acknowledged for her substantial contribution to the interpretation, summarization and presentation of data in this article and significant intellectual input to the manuscript. Dr. Murray is the founder and director of Medscript Ltd., a company that provides writing and editorial support for APEX COPD publications.

The authors received no direct compensation related to the development of the manuscript. Writing, editorial support, and/or formatting assistance was provided by Audrey Ang of the Observational and Pragmatic Research Institute, Singapore, and Dr. Buttle of Medscript Ltd, Ireland, which was funded by Boehringer Ingelheim Pharmaceuticals, Inc.

Boehringer Ingelheim was given the opportunity to review the manuscript for medical and scientific accuracy as well as intellectual property considerations.

\section{Declaration of Interest}

Chelsea Edwards is an employee of the company Optimum Patient Care, which is a co-founder of the APEX COPD initiative. Alan Kaplan is a member of the advisory board of, or speakers bureau for, Astra Zeneca, Boehringer Ingelheim, Grifols, GlaxoSmithKline, Merck Frosst, Novo Nordisk, Novartis, Paladdin, Pfizer, Purdue, Sanofi, Teva, and Trudel. Barbara Yawn has served on COPD-related advisory boards for GlaxoSmithKline, AstraZeneca, Novartis, and Boehringer Ingelheim, and received COPD-related investigator-initiated research funds from GlaxoSmithKline, Boehringer Ingelheim, AstraZeneca, and Novartis. Janwillem W. H. Kocks declares grants and personal fees from AstraZeneca, Boehringer Ingelheim, GlaxoSmithKline, and Novartis, and grants from Chiesi, Mundipharma and Teva. Lakmini Bulathsinhala is an employee of the company Optimum Patient Care, which is a co-founder of the APEX COPD initiative. Victoria Carter is an employee of the company Optimum Patient Care, which is a co-founder of the APEX COPD initiative. Ku-Lang Chang and Chester Fox declare no conflicts of interest. Gokul Gopalan is a former employee of Boehringer Ingelheim, which is a co-founder of the APEX COPD initiative and current employee of Vertex Pharmaceuticals. MeiLan Han reports consulting for Boehringer Ingelheim, GlaxoSmithKline and AstraZeneca, and research support from Novartis and Sunovion. Maja Kruszyk is an employee of the company Optimum Patient Care, which is a co-founder of the APEX COPD 
initiative. Chantal Le Lievre is an employee of the company Optimum Patient Care, which is a cofounder of the APEX COPD initiative. Cathy Mahle is an employee of the company Boehringer Ingelheim, which is a co-founder of the APEX COPD initiative. Barry Make reports funding from the National Heart, Lung and Blood Institute for the COPD Genetic Epidemiology study; grants and medical advisory boards from Boehringer Ingelheim, GlaxoSmithKline, AstraZeneca, and Sunovian; personal fees for DSMB from Spiration and Shire/Baxalta; CME personal fees from WebMD, National Jewish Health, American College of Chest Physicians, Projects in Knowledge, Hybrid Communications, SPIRE Learning, Ultimate Medical Academy, Catamount Medical, Eastern Pulmonary Society, Catamount Medical Communications Medscape, Eastern VA Medical Center, Academy Continued Healthcare Learning, and Mt. Sinai Medical Center; royalites from Up-ToDate; medical advisory boards from Novartis, Phillips, Third Pole, Science 24/7, and Vernoa; and grants from Pearl outside the submitted work. Wilson Pace is on the advisory board for Mylan and has stock from Novo Nordisk, Pfizer, Novartis, Johnson and Johnson, Stryker, Amgen, Gilead, and Sanofi. Chris Price is an employee of the company Optimum Patient Care, which is a co-founder of the APEX COPD initiative. Asif Shaikh is an employee of the company Boehringer Ingelheim, which is a co-founder of the APEX COPD initiative. Neil Skolnik is on advisory boards for AstraZeneca, Teva, Lilly, Boehringer Ingelheim, Sanofi, Janssen Pharmaceuticals, Intarcia, Mylan, and GlaxoSmithKline and has received payment for lectures/speaking engagements from AstraZeneca and Boehringer Ingelheim and research support from Sanofi, AstraZeneca, Boehringer Ingelheim, and
GlaxoSmithKline. David Price has board membership with Amgen, AstraZeneca, Boehringer Ingelheim, Chiesi, Circassia, Mylan, Mundipharma, Novartis, Regeneron Pharmaceuticals, Sanofi Genzyme, Teva Pharmaceuticals, Thermofisher; consultancy agreements with Amgen, AstraZeneca, Boehringer Ingelheim, Chiesi, GlaxoSmithKline, Mylan, Mundipharma, Novartis, Pfizer, Teva Pharmaceuticals, Theravance; grants and unrestricted funding for investigator-initiated studies (conducted through Observational and Pragmatic Research Institute Pte Ltd) from AstraZeneca, Boehringer Ingelheim, Chiesi, Circassia, Mylan, Mundipharma, Novartis, Pfizer, Regeneron Pharmaceuticals, Respiratory Effectiveness Group, Sanofi Genzyme, Teva Pharmaceuticals, Theravance, UK National Health Service; payment for lectures/speaking engagements from AstraZeneca, Boehringer Ingelheim, Chiesi, Cipla, GlaxoSmithKline, Kyorin, Mylan, Mundipharma, Novartis, Regeneron Pharmaceuticals, Sanofi Genzyme, Teva Pharmaceuticals; payment for the development of educational materials from Mundipharma, Novartis; payment for travel/ accommodation/meeting expenses from AstraZeneca, Boehringer Ingelheim, Mundipharma, Mylan, Novartis, Thermofisher; funding for patient enrollment or completion of research from Novartis; stock/stock options from AKL Research and Development Ltd which produces phytopharmaceuticals; owns $74 \%$ of the social enterprise Optimum Patient Care Ltd (Australia and UK) and 74\% of Observational and Pragmatic Research Institute Pte Ltd (Singapore); and is a peer reviewer for grant committees of the Efficacy and Mechanism Evaluation programme, and Health Technology Assessment. 


\section{References}

1. Wheaton AG, Cunningham TJ, Ford ES, Croft JB, Centers for Disease Control and Prevention (CDC). Employment and activity limitations among adults with chronic obstructive pulmonary disease-United States, 2013. MMWR Morb Mortal Wkly Rep. 2015;64(11):289-295.

2. Mannino DM, Gagnon RC, Petty TL, Lydick E. Obstructive lung disease and low lung function in adults in the United States: data from the National Health and Nutrition Examination Survey, 1988-1994. Arch Intern Med. 2000;160(11):1683-1689. doi: https://doi.org/10.1001/archinte.160.11.1683

3. Ma J, Ward EM, Siegel RL, Jemal A. Temporal Trends in Mortality in the United States, 1969-2013. JAMA. 2015;314(16):1731-1739. doi: https://doi.org/10.1001/jama.2015.12319

4. Lozano R, Naghavi M, Foreman K, et al. Global and regional mortality from 235 causes of death for 20 age groups in 1990 and 2010: a systematic analysis for the Global Burden of Disease Study 2010. Lancet Lond Engl. 2012;380(9859):2095-2128. doi: https://doi.org/10.1016/S0140-6736(12)61728-0

5. Murray CJL, Atkinson C, Bhalla K, et al. The state of US health, 1990-2010: burden of diseases, injuries, and risk factors. JAMA. 2013;310(6):591-608.

doi: https://doi.org/10.1001/jama.2013.13805

6. Ford ES, Murphy LB, Khavjou O, Giles WH, Holt JB, Croft JB. Total and state-specific medical and absenteeism costs of COPD among adults aged $\geq 18$ years in the United States for 2010 and projections through 2020. Chest. 2015;147(1):31-45. doi: https://doi.org/10.1378/chest.14-0972

7. Mathers CD, Loncar D. Projections of global mortality and burden of disease from 2002 to 2030. PLoS Med. 2006;3(11):e442. doi: https://doi.org/10.1371/journal.pmed.0030442

8. Global Initiative for Obstructive Lung Disease. Global strategy for the diagnosis, management and prevention of chronic obstructive pulmonary disease. 2020 Report. Published 2020. Accessed October 2020. https://goldcopd.org/wp-content/uploads/2019/12/GOLD2020-FINAL-ver1.2-03Dec19_WMV.pdf

9. Criner RN, Han MK. COPD care in the 21st century: a public health priority. Respir Care. 2018;63(5):591-600.

doi: https://doi.org/10.4187/respcare.06276

10. Diab N, Gershon AS, Sin DD, et al. Underdiagnosis and overdiagnosis of chronic obstructive pulmonary disease. Am J Respir Crit Care Med. 2018;198(9):1130-1139.

doi:https://doi.org/10.1164/rccm.201804-0621CI

11. Miller MR, Levy ML. Chronic obstructive pulmonary disease: missed diagnosis versus misdiagnosis. BMJ. 2015;351:h3021. doi: https://doi.org/10.1136/bmj.h3021

12. Cooke CE, Sidel M, Belletti DA, Fuhlbrigge AL. Review: clinical inertia in the management of chronic obstructive pulmonary disease. COPD. 2012;9(1):73-80.

doi: https://doi.org/10.3109/15412555.2011.631957
13. Gliklich RE, Dreyer NA, Leavy MB, eds. Registries for Evaluating Patient Outcomes: A User's Guide. 3rd ed. Agency for Healthcare Research and Quality; 2014. http://www.ncbi.nlm.nih.gov/books/ NBK208616/

14. Regan EA, Hokanson JE, Murphy JR, et al. Genetic epidemiology of COPD (COPDGene) study design. COPD. 2010;7(1):32-43. doi: https://doi.org/10.3109/15412550903499522

15. COPD Foundation. COPD Patient-Powered Research Network (PPRN). COPD Foundation website. Updated 2020. Accessed July 2020. https://www.copdfoundation.org/Research/COPD-Patient-PoweredResearch-Network/COPD-PPRN-Why-you-should-enroll.aspx

16. Jones RCM, Price D, Ryan D, et al. Opportunities to diagnose chronic obstructive pulmonary disease in routine care in the UK: a retrospective study of a clinical cohort. Lancet Respir Med. 2014;2(4):267-276. doi: https://doi.org/10.1016/S2213-2600(14)70008-6

17. Pill, J. The Delphi method: substance, context, a critique and an annotated bibliography. Socioecon Plann Sci. 1971;5:57-71. doi: https://doi.org/10.1016/0038-0121(71)90041-3

18. Eubank BH, Mohtadi NG, Lafave MR, et al. Using the modified Delphi method to establish clinical consensus for the diagnosis and treatment of patients with rotator cuff pathology. BMC Med Res Methodol. 2016;16:56.

doi: https://doi.org/10.1186/s12874-016-0165-8

19. Celli BR, MacNee W, Agusti A, et al. Standards for the diagnosis and treatment of patients with COPD: a summary of the ATS/ERS position paper. Eur Respir J. 2004;23(6):932-946. doi: https://doi.org/10.1183/09031936.04.00014304

20. Qaseem A, Snow V, Shekelle P, et al. Diagnosis and management of stable chronic obstructive pulmonary disease: a clinical practice guideline from the American College of Physicians. Ann Intern Med. 2007;147(9):633-638.

doi: https://doi.org/10.7326/0003-4819-147-9-200711060-00008

21. Qaseem A, Wilt TJ, Weinberger SE, et al. Diagnosis and management of stable chronic obstructive pulmonary disease: a clinical practice guideline update from the American College of Physicians, American College of Chest Physicians, American Thoracic Society, and European Respiratory Society. Ann Intern Med. 2011;155(3):179-191. doi: https://doi.org/10.7326/0003-4819-155-3-201108020-00008

22. Wedzicha JA, Calverley PMA, Albert RK, et al. Prevention of COPD exacerbations: a European Respiratory Society/American Thoracic Society guideline. Eur Respir J. 2017;50(3). doi: https://doi.org/10.1183/13993003.02265-2016

23. Wedzicha JA, Miravitlles M, Hurst JR, et al. Management of COPD exacerbations: a European Respiratory Society/American Thoracic Society guideline. Eur Respir J. 2017;49(3). doi: https://doi.org/10.1183/13993003.00791-2016 
24. Rennard S, Thomashow B, Crapo J, et al. Introducing the COPD Foundation Guide for Diagnosis and Management of COPD, recommendations of the COPD Foundation. COPD. 2013;10(3):378389. doi: https://doi.org/10.3109/15412555.2013.801309

25. Yang IA, Brown JL, George J, et al. COPD-X Australian and New Zealand guidelines for the diagnosis and management of chronic obstructive pulmonary disease: 2017 update. Med $J$ Aust. 2017;207(10):436-442. doi: https://doi.org/10.5694/mja17.00686

26. Global Initiative for Chronic Obstructive Lung Disease. Global strategy for the diagnosis, management, and prevention of chronic obstructive pulmonary disease,2018 update. Published 2018. Accessed July 2020. https://goldcopd.org/wp-content/uploads/2017/11/GOLD2018-v6.0-FINAL-revised-20-Nov_WMS.pdf

27. van der Molen T, Cazzola M. Beyond lung function in COPD management: effectiveness of LABA/LAMA combination therapy on patient-centred outcomes. Prim Care Respir J. 2012;21(1):101-108. doi: https://doi.org/10.4104/pcrj.2011.00102

28. de Marco R, Accordini S, Marcon A, et al. Risk factors for chronic obstructive pulmonary disease in a European cohort of young adults. Am J Respir Crit Care Med. 2011;183(7):891-897.

doi: https://doi.org/10.1164/rccm.201007-1125OC

29. Melani AS, Bonavia M, Cilenti V, et al. Inhaler mishandling remains common in real life and is associated with reduced disease control. Respir Med. 2011;105(6):930-938.

doi: https://doi.org/10.1016/j.rmed.2011.01.005

30. Chrystyn H, Small M, Milligan G, Higgins V, Gil EG, Estruch J. Impact of patients' satisfaction with their inhalers on treatment compliance and health status in COPD. Respir Med. 2014;108(2):358-365. doi: https://doi.org/10.1016/j.rmed.2013.09.021

31. Spruit MA, Singh SJ, Garvey C, et al. An official American Thoracic Society/European Respiratory Society statement: key concepts and advances in pulmonary rehabilitation. Am J Respir Crit Care Med. 2013;188(8):e13-64.

doi: https://doi.org/10.1164/rccm.201309-1634ST

32. Akins RB, Tolson H, Cole BR. Stability of response characteristics of a Delphi panel: application of bootstrap data expansion. BMC Med Res Methodol. 2005;5:37.

doi: https://doi.org/10.1186/1471-2288-5-37 